\title{
Assessment of Electric Power Generation Potential of Typical Forestry Biomass Resources in China
}

\author{
Zhibin Liu* \\ Department of Economics and Management \\ North China Electric Power University \\ Baoding, China \\ E-mail address: $\underline{\text { liuzhibin771112@126.com }}$
}

\author{
Xiaoning Li \\ Department of Economics and Management \\ North China Electric Power University \\ Baoding, China
}

\begin{abstract}
Carrying on the research of potential assessment of forestry biomass power generation in china systematically is significant not only theoretically but also realistically; it can guide the industry layout and reduce the operational costs of forestry biomass power generation in China. To assess the collectable amounts and power generation potential of forestry biomass resources in China, this paper selected the forestry residues resources as the research objects, determined the lower heating value and assessed the annual average power generation potential from 2011 to 2013 . The results showed that the maximum power generation potential of forestry biomass resources was $7125.31 \mathrm{MW}$. The power generation potential with more than 500MW was in Guangxi, Yunnan, Fujian and Guangdong, accounting for $\mathbf{4 3 . 4 1 \%}$ of the total forestry biomass power generation potential.
\end{abstract}

Keywords-China; forestry biomass resources; power generation potential; assessment

\section{INTRODUCTION}

With the rapid economic development and population growth, the global demand for electricity energy is increasing. At present, since the coal-based power generation still account for a large proportion in the total installed capacity, the energy security and greenhouse gas emissions and other issues are increasingly caused widespread concern in the international community. Expected global energy demand (oil equivalent) is projected to increase from $1.8 \mathrm{t}$ per capita in 2007 to $2.0 \mathrm{t}$ in 2030, and carbon dioxide emissions will rise from $4.4 \mathrm{t}$ in 2007 to $4.9 \mathrm{t}$ per capita in 2030 [1]. At the same time, countries around the world have announced their own emission reduction targets: In 2009, China and the United States respectively proposed that greenhouse gas emissions will be reduced by $40 \%-45 \%$ and $17 \%$ respectively by 2020 on the basis of 2005 level [2, 3]. Currently, China's thermal power generating capacity accounts for more than $70 \%$ of the total installed capacity, the energy structure is irrational, the power generation is inefficient and the greenhouse gas emissions is large. However, forestry biomass power generation has the advantages of low pollution, low emission and renewability. Meanwhile, the forest biomass reserves in China are relatively abundant, the power generation technology is mature, but its share in renewable energy power generation is far below the international average. Therefore, to develop forestry biomass power generation and other forms of renewable energy generation are one of the effective ways to optimize the energy structure and achieve emission reduction targets.

Currently, the research on biomass power generation at home and abroad is mainly focused on the status of power generation, power generation cost, power generation technology and government support policies [4-13], while few studies have been done on the potential of biomass power generation. As of the end of 2010, China's total installed capacity of biomass power generation has reached 5500MW, the government has also issued the "Medium and Long-term Development Plan of Renewable Energy" in August 2007 to determine that renewable energy power generation in the power system will rise to important power source before 2020, biomass power installed capacity reached $30000 \mathrm{MW}$, in which the agricultural and forestry biomass power generation will reach to $24000 \mathrm{MW}$. It is important to assess the resource reserves and power generation potentials of forestry biomass resources for realizing the renewable energy development planning and the normal operation of the power generation projects because of the wide distribution of forestry biomass resources. Based on this, this paper selects the "three residues" resources of forestry in China as the research objects to assess the resource collectible amounts and the generation potential respectively.

\section{MEthodology AND PARAMETER DETERMINATION}

Forest biomass resources refer to the energy provided in the process of forest growth and forestry production, including the energy forest directly derived from forests and the "three residues" resources of forestry derived from forests indirectly. Among them, the energy forest can be divided into wood energy forest and oil energy forest. Wood energy forest mainly refers to fuel woods (including trees and shrubs), which is to obtain the biomass fuel energy through the burning of wood components or chemical or physical conversion. Oil energy forests are energy forests in which the tree or a part is rich in oil or similar oil emulsion. The "three residues" resources of forestry mainly include the harvesting residues (branches, bark, leaves, trees and roots, etc. in the process of harvesting), the residues of timber (wood cuttings and cuttings produced during the initial processing of wood products etc.) and wood processing residues (the skin, slats, truncated, sawdust, shavings, wood and undercut materials, etc. are produced in the process of processing). 
In this paper, the "three residues" resources of forestry in China were taken as the research objects, combined with the relevant research and field investigation, determined the ratio of timber harvesting to woody biomass and wood processing residue to timber production, estimated the annual harvest, scrap and wood processing residues can be collected respectively from 2011 to2013, and then determined the low heating value of forest "three residues" resources and assessed its power generation potential. The assessment methods are as follows:

(1) Calculate the collectible amounts of forestry harvesting, processing residues

$$
\operatorname{FLBR}(j)=P(j) \times R_{F L B R}
$$

$F L B R(j)$ is the collectible amounts of forestry harvesting, processing residues in $j$ province, the unit of measurement is million cubic meters $\left(10^{4} \times \mathrm{m}^{3}\right)$.

$P(j)$ is the forest cutting quotas every year in $j$ province, the unit of measurement is $10^{4} \times \mathrm{m}^{3}$.

$R_{F L B R}$ is the ratio of harvesting, processing residues to forest biomass.

The forest cutting quotas can be founded in the "National Forest Cutting Quota Summary Table in Twelfth Five-Year Period". Based on the analysis of existing literature [14] and the sampling survey in the forest areas, it is determined that the ratio of timber harvest to woody biomass is $40 \%$.

(2) Calculate the collectible amounts of wood processing residues

$$
W M R(j)=M(j) \times R_{\text {WMR }}
$$

$W M R(j)$ is the collectible amounts of wood processing residues in $j$ province, the unit of measurement is $10^{4} \times \mathrm{m}^{3}$.

$M(j)$ is the production of timber every year in $j$ province, the unit of measurement is $10^{4} \times \mathrm{m}^{3}$.

$R_{W M R}$ is the ratio of wood processing residues to the production of timber.

The production of timber can be sorted out according to China Statistical Yearbook. Based on the analysis of existing literature $[14,15]$ and the sampling survey in the timber processing plant, and taking into account the actual situation around, it is determined that the ratio of wood processing residues to the production of timber is $34.4 \%$.

(3) Calculate the calorific value of "three residues" resources of forestry

$$
\operatorname{NFBE}(j)=10000 \times(\operatorname{FLBR}(j)+W M R(j)) \times C_{F T R} \times R_{V T W}
$$

$N F B E(j)$ is the calorific value of "three residues" resources of forestry in $j$ province, the unit of measurement is MJ.

$C_{F T R}$ is the lower heating value of "three residues" resources of forestry, the unit of measurement is MJ tonne $\mathrm{e}^{-1}$.

$R_{V T W}$ is the volume and weight conversion ratio of forestry "three residues" resources.
Considering the lower heating value of the main forest biomass resources in China [15] showed in Table I, the average lower heating value of "three residues" resources of forestry is $18709 \mathrm{MJ}^{-1} \mathrm{tonne}^{-1}$, and the volume and weight conversion ratio

\begin{tabular}{|c|c|c|c|c|}
\hline & \multicolumn{3}{|c|}{ RESOURCES } & 's: MJ TONNE"-1 \\
\hline Forest Species & Pine & China fir & Poplar & Willow \\
\hline Lower heating value & 19045 & 19194 & 17933 & 18625 \\
\hline
\end{tabular}
of forestry "three residues" resources is 0.44 [14].

TABLE I. THE LOWER HEATING VALUE OF MAIN FOREST BIOMASS

CONTINUED TABLE

\begin{tabular}{|c|c|c|c|c|}
\hline Forest Species & Birch & Maple & Beech & Rosewood \\
\hline Lower heating value & 18413 & 18902 & 18077 & 19485 \\
\hline
\end{tabular}

(4) Calculate the generation potential of "three residue" resources of forestry

$$
\operatorname{FBPP}(j)=\frac{K \times N F B E(j)}{T}
$$

Where $F B P P(j)$ is the generation potential of "three residues" resources of forestry in $j$ province, the unit of measurement is MW.

$K$ is the overall energy conversion efficiency.

$T$ is the annual sustained run time; the unit of measurement is second(s).

In the current study, the conservative estimate of $\mathrm{K}$ is $20 \%$, and the annual sustained run time is calculated on an annual basis.

\section{EVALUATION RESULTS AND ANALYSIS}

\section{A. Collectible Amount of "Three Residues" Resources in Forestry in China}

This paper took 31 provinces, autonomous regions and municipalities (excluding Taiwan, Hong Kong and Macao) as the research area, and the Chinese "three residues" resources were taken as the research objects. Based on the data of China Statistical Yearbook (2011-2013) and the "National Forest Cutting Quota Summary Table in Twelfth Five-Year Period", the total amount of "three residues" resources of forestry in China could be calculated (Table II). The total collectable amounts of forestry "three residues" resources in China were 136.4826 million cubic meters, mainly distributed in Guangxi, Yunnan, Fujian, Guangdong, Hunan, Jiangxi, Sichuan, Jilin, Heilongjiang and Anhui 10 provinces, accounting for $15.40 \%$, $11.22 \%, 8.91 \%, 7.89 \%, 6.60 \%, 6.56 \%, 4.20 \%, 3.87 \%, 3.86 \%$ and $3.75 \%$ respectively, and the total reached $72.24 \%$. 
TABLE II. THE ANNUAL COLLECTABLE AMOUNTS OF FORESTRY RESIDUES FROM 2011 TO 2013

UNITS: $10^{4} \times \mathrm{M}^{3}$

\begin{tabular}{|c|c|c|c|c|c|c|c|}
\hline Number & Province & $\begin{array}{l}\text { Annual Forest } \\
\text { Cutting Quota }\end{array}$ & $\begin{array}{c}\text { Annual Collectable } \\
\text { Amounts of Logging and } \\
\text { Cross-cutting Residues }\end{array}$ & $\begin{array}{c}\text { Annual Timber } \\
\text { Output }\end{array}$ & $\begin{array}{c}\text { Annual Collectable } \\
\text { Amounts of Wood } \\
\text { Processing Residues }\end{array}$ & $\begin{array}{c}\text { Total Collectable } \\
\text { Amounts of } \\
\text { Forestry Residues }\end{array}$ & $\begin{array}{l}\text { Proportion } \\
\text { (\%) }\end{array}$ \\
\hline 1 & Guangxi & 3681.80 & 1472.72 & 1827.36 & 628.61 & 2101.33 & 15.40 \\
\hline 2 & Yunnan & 3399.10 & 1359.64 & 497.79 & 171.24 & 1530.88 & 11.22 \\
\hline 3 & Fujian & 2550.00 & 1020.00 & 568.76 & 195.65 & 1215.65 & 8.91 \\
\hline 4 & Guangdong & 2030.00 & 812.00 & 768.17 & 264.25 & 1076.25 & 7.89 \\
\hline 5 & Hunan & 1809.40 & 723.76 & 513.99 & 176.81 & 900.57 & 6.60 \\
\hline 6 & Jiangxi & 1996.80 & 798.72 & 281.27 & 96.76 & 895.48 & 6.56 \\
\hline 7 & Sichuan & 1226.10 & 490.44 & 241.06 & 82.92 & 573.36 & 4.20 \\
\hline 8 & Jilin & 996.60 & 398.64 & 375.32 & 129.11 & 527.75 & 3.87 \\
\hline 9 & Heilongjiang & 1001.90 & 400.76 & 364.50 & 125.39 & 526.15 & 3.86 \\
\hline 10 & Anhui & 857.90 & 343.16 & 489.34 & 168.33 & 511.49 & 3.75 \\
\hline 11 & Shandong & 823.20 & 329.28 & 486.24 & 167.27 & 496.55 & 3.64 \\
\hline 12 & Hubei & 1000.60 & 400.24 & 267.58 & 92.05 & 492.29 & 3.61 \\
\hline 13 & Guizhou & 842.30 & 336.92 & 196.79 & 67.70 & 404.62 & 2.96 \\
\hline 14 & $\begin{array}{c}\text { Inner } \\
\text { Mongolia } \\
\end{array}$ & 773.10 & 309.24 & 204.31 & 70.28 & 379.52 & 2.78 \\
\hline 15 & Henan & 577.80 & 231.12 & 266.86 & 91.80 & 322.92 & 2.37 \\
\hline 16 & Zhejiang & 635.00 & 254.00 & 162.52 & 55.91 & 309.91 & 2.27 \\
\hline 17 & Liaoning & 536.20 & 214.48 & 189.09 & 65.05 & 279.53 & 2.05 \\
\hline 18 & Shanxi & 631.30 & 252.52 & 26.92 & 9.26 & 261.78 & 1.92 \\
\hline 19 & Hainan & 400.00 & 160.00 & 115.05 & 39.58 & 199.58 & 1.46 \\
\hline 20 & Jiangsu & 155.30 & 62.12 & 161.21 & 55.46 & 117.58 & 0.86 \\
\hline 21 & Hebei & 225.20 & 90.08 & 76.90 & 26.45 & 116.53 & 0.85 \\
\hline 22 & Tibet & 210.10 & 84.04 & 60.24 & 20.72 & 104.76 & 0.77 \\
\hline 23 & Sinkiang & 208.40 & 83.36 & 38.36 & 13.20 & 96.56 & 0.71 \\
\hline 24 & Shanxi & 144.50 & 57.80 & 9.83 & 3.38 & 61.18 & 0.45 \\
\hline 25 & Chongqing & 119.70 & 47.88 & 29.60 & 10.18 & 58.06 & 0.43 \\
\hline 26 & Gansu & 111.20 & 44.48 & 4.28 & 1.47 & 45.95 & 0.34 \\
\hline 27 & Beijing & 40.00 & 16.00 & 15.14 & 5.21 & 21.21 & 0.16 \\
\hline 28 & Tianjin & 12.40 & 4.96 & 11.98 & 4.12 & 9.08 & 0.07 \\
\hline 29 & Qinghai & 15.60 & 6.24 & 1.61 & 0.55 & 6.79 & 0.05 \\
\hline 30 & Ningxia & 8.30 & 3.32 & 0.83 & 0.28 & 3.60 & 0.03 \\
\hline 31 & Shanghai & 3.20 & 1.28 & 0.18 & 0.06 & 1.34 & 0.01 \\
\hline 32 & Total & 27023.00 & 10809.20 & 8253.09 & 2839.06 & 13648.26 & 100.00 \\
\hline
\end{tabular}

B. Electric Power Generation Potential of "Three Residues" Resources in Forestry in China

The provincial power potential of forestry residues resources in China was showed as Table III. In Guangxi, Yunnan, Fujian and Guangdong four provinces, the electric power generation potential of "three residues" resources in forestry is 500 Megawatts or more, accounting for $43.41 \%$ of its total generating capacity. While the power generation potential is 200-500 MW in 9 provinces of Hunan, Jiangxi, Sichuan, Jilin, Heilongjiang, Anhui, Shandong, Hubei and Guizhou, accounting for the proportion of $39.04 \%$. The other 18 provinces only have the potential below 200MW, accounting for $17.55 \%$ of its total generating capacity. 
TABLE III. THE PROVINCIAL POWER POTENTIAL OF FORESTRY RESIDUES RESOURCES IN CHINA

UNITS: MW

\begin{tabular}{|c|c|c|c|c|c|}
\hline Number & Province & \multicolumn{2}{|c|}{ Power Generation Potential } & \multicolumn{2}{|c|}{ Proportion (\%) } \\
\hline 1 & Guangxi & 1097.04 & \multirow{4}{*}{$>500$} & 15.40 & \multirow{4}{*}{43.41} \\
\hline 2 & Yunnan & 799.22 & & 11.22 & \\
\hline 3 & Fujian & 634.65 & & 8.91 & \\
\hline 4 & Guangdong & 561.88 & & 7.89 & \\
\hline 5 & Hunan & 470.16 & \multirow{9}{*}{$200-500$} & 6.60 & \multirow{9}{*}{39.04} \\
\hline 6 & Jiangxi & 467.50 & & 6.56 & \\
\hline 7 & Sichuan & 299.33 & & 4.20 & \\
\hline 8 & Jilin & 275.52 & & 3.87 & \\
\hline 9 & Heilongjiang & 274.69 & & 3.86 & \\
\hline 10 & Anhui & 267.03 & & 3.75 & \\
\hline 11 & Shandong & 259.23 & & 3.64 & \\
\hline 12 & Hubei & 257.01 & & 3.61 & \\
\hline 13 & Guizhou & 211.24 & & 2.96 & \\
\hline 14 & Inner Mongolia & 198.14 & \multirow{18}{*}{$<200$} & 2.78 & \multirow{18}{*}{17.55} \\
\hline 15 & Henan & 168.59 & & 2.37 & \\
\hline 16 & Zhejiang & 161.79 & & 2.27 & \\
\hline 17 & Liaoning & 145.93 & & 2.05 & \\
\hline 18 & Shanxi & 136.67 & & 1.92 & \\
\hline 19 & Hainan & 104.19 & & 1.46 & \\
\hline 20 & Jiangsu & 61.38 & & 0.86 & \\
\hline 21 & Hebei & 60.84 & & 0.85 & \\
\hline 22 & Tibet & 54.69 & & 0.77 & \\
\hline 23 & Sinkiang & 50.41 & & 0.71 & \\
\hline 24 & Shanxi & 31.94 & & 0.45 & \\
\hline 25 & Chongqing & 30.31 & & 0.43 & \\
\hline 26 & Gansu & 23.99 & & 0.34 & \\
\hline 27 & Beijing & 11.07 & & 0.16 & \\
\hline 28 & Tianjin & 4.74 & & 0.07 & \\
\hline 29 & Qinghai & 3.55 & & 0.05 & \\
\hline 30 & Ningxia & 1.88 & & 0.03 & \\
\hline 31 & Shanghai & 0.70 & & 0.01 & \\
\hline 32 & Total & 7125.31 & - & 100.00 & 100.00 \\
\hline
\end{tabular}

\section{CONCLUSIONS}

The total collectable amounts of forestry "three residues" resources in China is $13648.2610^{4} \times \mathrm{m}^{3}$, which is mainly distributed in 10 provinces in Guangxi, Yunnan, Fujian, Guangdong, Hunan, Jiangxi, Sichuan, Jilin, Heilongjiang and Anhui, accounting for $72.24 \%$ of the total collectable amounts. The power generation potential of China's forestry "three residue" resources is $7125.31 \mathrm{MW}$, and more than $40 \%$ of the power generation potential is concentrated in four provinces which possess more resources. Power generation potential of 500 Megawatts or more is mainly in Guangxi, Yunnan, Fujian and Guangdong, accounted for $43.41 \%$ of its total generating capacity. In 9 provinces of Hunan, Jiangxi, Sichuan, Jilin, Heilongjiang, Anhui, Shandong, Hubei and Guizhou, the power generation potential is $200-500 \mathrm{MW}$, accounting for
$39.04 \%$ of the total generating potential. And the remaining 18 provinces have a potential of 200 Megawatts or less.

Based on the assessment of the power potential of the forestry "three residues" resources, the development areas of China's forestry biomass power generation industry are divided into three categories: (I) the power potential is 500 Megawatts or more, including Guangxi, Fujian, Yunnan and Guangdong provinces; (II) the power generation potential is $200-500 \mathrm{MW}$, including 9 provinces of Hunan, Jiangxi, Sichuan, Jilin, Heilongjiang, Anhui, Shandong, Hubei, Guizhou; (III) with a potential of 200 megawatts or less, including 18 provinces, autonomous regions and municipalities other than the first and second categories.

Although the forestry biomass power generation has the characteristics of low pollution and low emission, the cost of its 
investment, raw material collection and transportation are higher. Currently, some biomass power generation enterprises are at a loss, mainly rely on the national policy support to maintain operations. Therefore, through the calculation and analysis of the biomass potential and development area of forestry biomass resources in provinces, autonomous regions and municipalities in China, considering the cost of raw materials and documentation requirements, it is considered suitable for industrialized development of biomass power generation in the first and second types of areas. By cooperating with powerful enterprises both at home and abroad, we can build biomass power generation equipment manufacturing base in the region and realize the localized production of power generation equipment, strive to make the domestically produced equipment reach more than $70 \%$ of the total equipment. Furthermore, it should attract scientific research, education and consulting intermediaries to participate actively, strengthen the effect of joint action, and then realize the cluster development of biomass power industry.

\section{ACKNOWLEDGMENT}

This paper was supported by "the Social Science Fund Projects in Hebei Province (HB14YJ031)" and "the Fundamental Research Funds for the Central Universities".

\section{REFERENCES}

[1] International Energy Agency, "How the energy sector can deliver on a climate agreement in Copenhagen," Paris: Organization for Economic Co-operation and Development / International Energy Agency, pp. 1718, 2009.

[2] Ren H. j., "Determine the reduction targets of greenhouse gas emissions in the United States," http://news.xinhuanet.com/environment/200911/26/content_12542443.htm, 2009-11-26. (In Chinese)
[3] Liu H., Niu Q., Wang J. H., "Declare the quantification reduction targets of greenhouse gas emissions clearly for the first time in China," http://news.sohu.com/20091126/n268497227.shtml, 2009-11-26. (In Chinese)

[4] Aguilar, F. X., Song, N., Shifley, S., "Review of consumption trends and public policies promoting woody biomass as an energy feedstock in the US,” Biomass \& Bioenergy, pp. 3708-3718, no. 8, 2011.

[5] Edward M.W. Smeets, André P.C. Faaij, "The impact of sustainability criteria on the costs and potentials of bioenergy production-Applied for case studies in Brazil and Ukraine," Biomass and Bioenergy, pp. 319333, no. 3, 2010.

[6] La Scalia, G., Aiello, G., Micale, R., "Biomass power plants in western Sicily, Italy," Waste Management, pp. 2191-2192, no. 9-10, 2011.

[7] Lenis Y.A., Agudelo A.F., Perez J.F., "Analysis of statistical repeatability of a fixed bed downdraft biomass gasification facility," Applied Thermal Engineering, pp. 1006-1016, no. 1-2, 2013.

[8] Liu, J. C., Wang, S. J., Wei, Q. S., et al., "Present situation, problems and solutions of China's biomass power generation industry," Energy Policy, pp. 144-151, no. 7, 2014.

[9] Moonmoon Hiloidhari, Debendra Chandra Baruah, "Rice straw residue biomass potential for decentralized electricity generation: A GIS based study in Lakhimpur district of Assam, India," Energy for Sustainable Development, pp. 214-222, no. 3, 2011.

[10] P.W. Adams, G.P. Hammonda, M.C. McManus, et al., "Barriers to and drivers for UK bioenergy development," Renewable and Sustainable Energy Reviews, pp. 1217-1227, no. 15, 2011.

[11] Zhang Q., Zhou D. Q., Fang X. M., et al., "Analysis on the policies of biomass power generation in China," Renewable and Sustainable Energy Reviews, pp. 926-935, no. 4, 2014.

[12] Zhao, X. G., Wang, J. Y., Liu, X. M., et al., "Focus on situation and policies for biomass power generation in China," Renewable and Sustainable Energy Reviews, pp. 3733-3729, no. 6, 2012.

[13] Zhao Z. Y., Yan H., "Assessment of the biomass power generation industry in China,” Renewable Energy, pp. 53-60, no. 1, 2012.

[14] Tian Y. S., Biomass Power Generation. Beijing: Chemical Industry Press, 2010. (In Chinese)

[15] Chang J. M., Forest Biomass Resources and Energy Utilization Technology. Beijing: Science Press, 2010. (In Chinese) 